S.Ü. Müh. Bilim ve Tekn. Derg., c.6, Özel Sayı, ss. 825-831, 2018

Selcuk Univ. J. Eng. Sci. Tech., v.6, Special Issue, pp. 825-831, 2018

ISSN: 2147-9364 (Electronic)

SELÇUK

DOI: 10.15317/Scitech.2018.172

ÜNIVERSITTESİ

EURASIAN GIS CONGRESS 2018

\title{
COMPARISON OF TOPSIS AND VIKOR MULTI CRITERIA DECISION ANALYSIS TECHNIQUES
}

\author{
1Fatih SARI \\ ${ }^{1}$ Selcuk University, Cumra School of Applied Sciences, Cumra, Konya,Turkey \\ 1 fatihsari@selcuk.edu.tr
}

(Geliş/Received: 08.11.2018; Kabul/Accepted in Revised Form: 21.12.2018)

\begin{abstract}
Nowadays, beside Geographical Information Systems (GIS) analysis capabilities, Multi Criteria Decision Analysis (MCDA) techniques have been applied to a large amount of spatial decision problems. MCDA techniques are widely used in different kind of site suitability analysis in the field of environmental, engineering, topographical, social and economic perspectives. When planners are giving decision to related problems, there are limitations, expectations and requirements are involved in this stage. Right decision giving require to characterize the complex criteria structure and select appropriate data.

The most used MCDA techniques in GIS are Analytical Hierarchy Process (AHP), The Technique for Order of Preference by Similarity to Ideal Solution (TOPSIS) and Vise Kriterijumska Optimizacija I Kompromisno Resenje (VIKOR). In this study, TOPSIS and VIKOR techniques are compared to each other according to the models and capabilities.
\end{abstract}

Key Words: AHP, Geographical information systems, Multi criteria decision techniques, TOPSIS, VIKOR

\section{TOPSIS VE VIKOR Çok Ölçütlü Karar Analizlerinin Karşılaştırılması}

ÖZ: Günümüzde, Coğrafi Bilgi Sistemleri (CBS) analiz yeteneklerinin yanı sıra, çok ölçütlü karar problemlerine Çok Ölçütlü Karar Analizi (MCDA) teknikleri uygulanmıştır. MCDA teknikleri, çevre, mühendislik, topoğrafik, sosyal ve ekonomik perspektifler alanında farklı tipte saha uygunluk analizlerinde yaygın olarak kullanılmaktadır. Plancılar ilgili sorunlara karar verdiğinde, bu aşamada sınırlamalar, beklentiler ve gereksinimler söz konusudur. Doğru karar verme, karmaşık kriter yapısını tanımlamak ve uygun verileri seçmek için gereklidir.

CBS'de en çok kullanılan MCDA teknikleri, Analitik Hiyerarşi Prosesi (AHP), İdeal Çözüm ile Benzerlik Sırasına Göre Tercih Sırası Tekniği (TOPSIS) ve Vise Kriterijumska Optimizacija I Kompromisno Resenje'dir (VIKOR). Bu çalışmada, TOPSIS ve VIKOR teknikleri, model ve kabiliyetlere göre birbirleriyle karşılaştırılmıştır.

Anahtar Kelimeler: AHP, Coğrafi bilgi sistemleri, Çok ölçütlü karar analizi, TOPSIS, VIKOR

\section{INTORDUCTION}

Decision makers have to work in very complex conditions - fast-changing, overloaded with information and comprehensive decision making. Multi-Criteria Decision Analysis (MCDA) refers to making decision in the presence of multiple criteria.

Problems in daily life require considering complex structure of criteria which have effect on solutions and results (Baizyldayeva et al., 2013). 
MCDA methods provide a platform to evaluate the criteria and have some characteristics;

- Criteria, can be an attribute or spatial data

- Conflicting criteria, the conflicts and similarities of each criterion against each other.

- Units, each criterion can be in a different measure unit.

- Flexible design, the structure of weight calculation is completely flexible.

MCDA concept involves different kind of methods to give decision with multiple and conflicting criteria. Analytical Hierarchy Process (AHP) is the most mentioned methods in MCDA and is a general term that refers to the applications used to determine the most suitable solution to the real problems by providing a selection from different data clusters compared to others such as The Technique for Order of Preference by Similarity to Ideal Solution (TOPSIS) and Vise Kriterijumska Optimizacija I Kompromisno Resenje (VIKOR) due to the high applicability rate of AHP to a wide range of disciplines for spatial and non-spatial data (Hwang and Yoon, 1981; Arentze and Timmermans, 2000). TOPSIS is based on determining the best alternative which has the shortest distance to positive ideal solution and longest distance from negative ideal solution (Hwang and Yoon, 1981). The positive ideal solution represents the maximized benefit criteria and minimized cost criteria. In other words, the negative ideal solution represents the maximized cost criteria and minimized benefit criteria (Wang and Elhag, 2006; Ho et al, 2010; Sakthivel et al, 2015). Finally, the VIKOR method is a MCDA method to determine the compromise ranking and compromise solution via given criteria weights. The VIKOR focuses on ranking and selecting from a set of alternatives by multi-criteria ranking index based on a measuring the distances to the ideal solution. The compromise ranking list can be determined by calculating the closeness of alternatives to the ideal solution (Opricovic, 1998). In an outranking method PROMETHEE it is possible to define different preference functions for criteria (Brans et al. 1984: Brans and Vincle 1985; 1986). It is well adapted to the problems where a finite set of alternatives are to be ranked according to several, sometimes conflicting criteria (Albadvi et al, 2007). One of the main advantages of PROMETHEE is the simplicity of its methodology in comparison to the other outranking techniques (like TOPSIS, VIKOR and ELECTRE) and the Preference functions support which provides more realistic definition for real problems (Senvar et al, 2014).

In this study, VIKOR and TOPSIS methods are compared considering the structure of evaluation techniques.

\section{Analytical Hierarchy Process (AHP)}

The procedure outlined by (Saaty, 1977; Saaty, 1980) scales the importance of each criterion, from 1 to 9 relatively (1=Equal, $3=$ Moderately, $5=$ Strongly, $7=$ Very, 9=Extremely). The pairwise comparison matrix includes the scales (ann) and determines the importance of criteria.

\begin{tabular}{|c|c|c|c|c|c|}
\hline$A$ & Criteria 1 & Criteria 2 & Criteria 3 & $\ldots$ & Criteria $n$ \\
\hline Criteria 1 & $a_{19}$ & $a_{19}$ & $a_{9 \Phi}$ & $\ldots$ & $a_{\mathrm{yn}}$ \\
\hline Criteria 2 & $a_{21}$ & $a_{2 z}$ & $a_{2 \pi}$ & $\ldots$ & $a_{2 n}$ \\
\hline$\ldots$ & $\ldots$ & $\cdots$ & $\cdots$ & $\cdots$ & $\ldots$ \\
\hline Criteria $n$ & $a_{\operatorname{mi}}$ & $a_{\text {nix }}$ & $a_{\max }$ & $\ldots$ & $a_{\min }$ \\
\hline
\end{tabular}

Each element of the comparison matrix is divided by the sum of its own column sum to generate a normalized matrix. 


$$
a_{i j}^{1}=\frac{a_{i j}}{\sum_{i=1}^{\mathrm{n}} a_{i j}}
$$

The average of the sum represents the weights of each criterion in pairwise comparison matrix.

$$
w_{i}=\left(\frac{1}{n}\right) \sum_{i=1}^{n} a_{i j}^{s}, \quad(i, j=1,2,3, \ldots, n)
$$

The consistency of the pairwise comparison matrix must be calculated to decide the criteria, comparisons are consistent or not. Consistency Index (CI) is one of the methods to define the consistency coefficient of the pairwise comparison matrix. CI is calculated with Formula 4 (Saaty, 1994).

$$
C I=\frac{\lambda_{\max }-n}{n-1}
$$

Calculating consistency index depends on the $\lambda_{\max }$ (eigen value) value and Random Index $(R I)$ value according to the matrix order.

$$
\lambda_{\max }=\frac{1}{n} \sum_{i=1}^{n}\left[\frac{\sum_{j=1}^{n} a_{i j} w_{j}}{w_{i}}\right]
$$

After calculating the $\mathrm{CI}$ and $\mathrm{RI}$, consistency ratio $(\mathrm{CR})$ can be calculated with Formula 6 . If $\mathrm{CR}$ exceeds 0.1, based on expert knowledge and experience (Saaty and Vargas, 1991), recommends a revision of the pairwise comparison matrix with different values (Saaty, 1980).

$$
C R=\frac{C I}{R I}
$$

\section{TOPSIS}

TOPSIS method was introduced by Hwang and Yoon (1981), considering that alternatives have shortest distance to positive ideal solution and longest distance to negative ideal solution. The ranking which made by TOPSIS is a result of evaluating the distances of alternatives to the ideal solution within each criteria (Eleren and Karagül, 2008; Kalkan et al., 2017).

The best ranked solution, which is determined as positive ideal solution, is a solution that maximizes the benefit and minimizes the cost criterion. Similarly, the negative ideal solution is a solution that maximizes the cost and minimizes the benefit (Wang and Elhag, 2006). In TOPSIS method, results can be determined by ranking the values which represent the relative distances. (Cheng et al, 2002).

In evaluation matrix $\mathrm{Ai}, \mathrm{A}=\left(1_{r} 2_{, x_{y}} \mathrm{n}\right)$ represents the alternatives and $\mathrm{Ci}, \mathrm{C}=\left(1_{r} 2_{y x} \mathrm{~m}\right)$ a set of criteria; where $\mathrm{Xi}_{\mathrm{i}}\left(\mathrm{X}_{11}\right.$ to $\left.\mathrm{Xnm}\right)$ defines the ratings.

\begin{tabular}{|c|ccccc|}
\hline \multicolumn{2}{|c}{$\boldsymbol{C}_{\boldsymbol{1}}$} & $\boldsymbol{C}_{2}$ & $\boldsymbol{C}_{3}$ & & $\boldsymbol{C}_{\boldsymbol{m}}$ \\
\hline $\boldsymbol{A}_{\boldsymbol{1}}$ & $X_{11}$ & $X_{12}$ & $X_{13}$ & $\ldots$ & $X_{1 m}$ \\
$\boldsymbol{A}_{2}$ & $X_{21}$ & $X_{22}$ & $X_{23}$ & $\ldots$ & $X_{2 m}$ \\
$\ldots$ & $\ldots$ & $\ldots$ & $\ldots$ & $\ldots$ & $\ldots$ \\
$\boldsymbol{A}_{n}$ & $X_{n 1}$ & $X_{n 2}$ & $X_{n 3}$ & $\ldots$ & $X_{n m}$ \\
\hline
\end{tabular}


$R$ and $V$ matrices represent normalized weighted decision matrices considering the ratings (Hwang and Yoon, 1981).

$$
\begin{aligned}
& n_{i j}(x)=\frac{x_{i j}}{\sqrt{\sum_{i=1}^{m} x_{i j}^{2}}}, \quad i=1_{s \ldots s} n, j=1_{w} \ldots m \\
& v_{i j}(x)=w_{i} x x_{i j}(x), i=1_{w \ldots} n, j=1_{, \ldots} m
\end{aligned}
$$

While positive ideal solution consists of the largest element of weighted normalized decision matrix $V$, negative ideal solution consists of the smallest element.

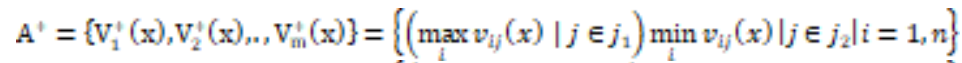

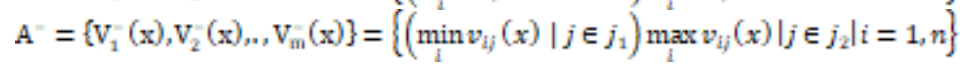

$\mathrm{Di}^{*}$ and $\mathrm{Di}^{-}$calculations refer to the separation of the alternatives from the positive and negative ideal solutions via Euclidean distance calculation. The number of $\mathrm{Di}^{*}$ and $\mathrm{Di}^{-}$will be equal to the number of alternatives (Triantaphyllou, 2000; Peters and Zelewski, 2007).

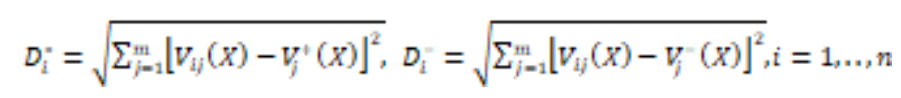

As a result, relative closeness to the ideal solution $\mathrm{Ci}^{*}\left(1>\mathrm{Ci}^{*}>0\right)$ decides better solution with closeness to 1 .

$$
C_{i}^{*}=\frac{D_{k}^{-}}{D_{k}^{*}+D_{k}^{-}}, \quad C_{i}^{*} \in[0,1], \forall i=1, \ldots, n
$$

\section{VIKOR}

VIKOR method has been proposed by Opricovic and Tzeng (2004) to solve multi criteria decision making problems (Opricovic and Tzeng, 2004). On the assumption that each alternative is evaluated for each criterion, with the weights determined in the VIKOR method, the compromised ranking is obtained by comparing their ideal proximity values for ideal alternative (Opricovic and Tzeng, 2007).

Development of the VIKOR method started with the following form of Lp-metric;

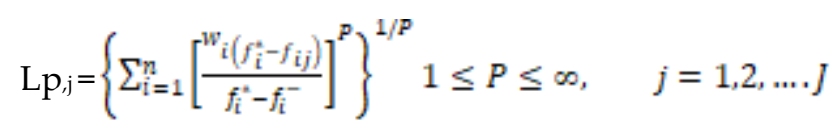

Within the VIKOR method $L 1, j=S_{j}$ and $L_{\infty} j=R_{j}$ are used to formulate the ranking measure. The minimum $S_{j}$ solution represents the maximum group utility and the minimum solution $R_{j}$ represents the individual regret of the opponent (Yu, 1973; Zeleny, 1982; Opricovic, 1998).

Best $\mathrm{f}_{\mathrm{i}}^{*}$ and the worst $\mathrm{f}_{\mathrm{i}}^{-}$values of all criterion functions $(\mathrm{i}=1,2, . ., \mathrm{n})$,

$$
\begin{gathered}
f_{i}^{*}=\max _{j} f_{i j}, f_{i}^{-}=\min _{j} f_{i j}, \quad \text { represents a benefit } \\
f_{i}^{*}=\min _{j} f_{i j}, f_{i}^{-}=\max _{j} f_{i j} \quad \text { represents a cost }
\end{gathered}
$$


will be used to compute the values $S_{j}$ and $R_{j}$,

$$
S_{j}=\frac{\sum_{i=1}^{n} w_{i}\left(f_{i}^{*}-f_{i j}\right)}{\left(f_{i}^{*}-f_{i j}\right)}, R_{j}=\max _{i}\left[\frac{W_{i}\left(f_{i}^{*}-f_{i j}\right)}{\left(f_{i}^{*}-f_{i j}\right)}\right], \quad \mathrm{j}=1,2, \ldots, \mathrm{J}_{x}
$$

where wi are the weights of criteria, expressing their relative importance.

Compute the values Qj; $j=1,2, \ldots, m$,

$$
Q_{j}=\frac{v\left(s_{j}-s^{*}\right)}{\left(s^{-}-s^{*}\right)}+\frac{(1-v)\left(R_{j}-R^{*}\right)}{\left(R^{-}-R^{*}\right)}
$$

where $S^{*}=\min _{j} S_{j}, S^{-}=\max _{j} S_{j}, R^{*}=\min _{j} R_{j}, R^{-}=\max _{j} R_{j}$

The best ranked $Q$ (minimum) measure is proposed as a compromise solution.

\section{Comparison of Techniques}

Both methods assume a scale factor for each criterion. This scale requires eliminating the different units of all criteria values. For ranking the values that calculated by methods are defined with an aggregating function. The main difference between two methods appears in the aggregation approaches. The VIKOR method provides an aggregating function representing the distances from ideal solution. Addition to TOPSIS, VIKOR method provides a compromise solution with an advantage rate.

The normalization procedures are different in each method. While the VIKOR method uses linear normalization, TOPSIS method uses vector normalization. In linear normalization, the normalized value does not depend to the unit of the criteria. In TOPSIS method, normalized value could be different for different evaluation unit of a particular criterion (Opricovic and Tzeng, 2004).

The TOPSIS method introduces the ranking index including the distances from the ideal point and from the negative-ideal (nadir) point. These distances in TOPSIS are simply summed without considering their relative importance (Opricovic and Tzeng, 2004).

The TOPSIS method uses n-dimensional Euclidean distance that by itself could represent some balance between total and individual satisfaction, but uses it in a different way than VIKOR, where weight $\mathrm{v}$ is introduced. Both methods provide a ranking list. The highest ranked alternative by VIKOR is the closest to the ideal solution. However, the highest ranked alternative by TOPSIS is the best in terms of the ranking index, which does not mean that it is always the closest to the ideal solution. In addition to ranking, the VIKOR method proposes a compromise solution with an advantage rate (Opricovic and Tzeng, 2004).

\section{DISCUSSION}

Both methods VIKOR and TOPSIS are mostly used MCDA methods in decision making projects. Ability to adapt methods to Geographical Information Systems increase the applicability in the field of environmental, meteorological and engineering problems. Different solutions enhance the decision process and increase the preference of decision makers. Thus, right decision giving can be possible with two probabilities.

These two MCDM methods use different kinds of normalization to eliminate the units of criterion functions, whereas the VIKOR method uses linear normalisation, the TOPSIS method uses vector normalization. The normalized value in the VIKOR method does not depend on the evaluation unit of a criterion function, whereas the normalized values by vector normalization in the TOPSIS method may depend on the evaluation unit. 
The differences of the methods could be realized better with a numerical example to compare the results more evidently. The result maps should be evaluated carefully to make a comparison of methods. For instance, a criterion could be more evident and effective in result maps. As a result, the maps should be verified with correlation analyses to decide which method is more suitable for specified problem and which consistency value could methods offer

\section{REFERENCES}

Albadvi, A, Chaharsooghi, S.K., Esfahanipour, A., 2007, "Decision Making in Stock Trading: an Application of PROMETHEE", Eur. J. Oper. Res., Vol. 177(2), pp. 673-683.

Arentze, T. A., Timmermans, H. J. P., 2000, “ALBATROSS: A Learning-based Transportation Oriented Simulation System", EIRASS, Eindhoven University of Technology, The Netherlands.

Baizyldayeva, U., Vlasov,O., Kuandykov, A., Akhmetov, T., 2013, "Multi-Criteria Decision Support Systems", Comparative Analysis, Middle-East Journal of Scientific Research, Vol. 16(12), pp. 17251730.

Brans, J.P, Mareschal, B, Vincke, P., 1984, “PROMETHEE: A New Family of Outranking Methods in MCDM". In: Brans J.P. (ed.) Operational Research IFORS 84. North-Holland, Amsterdam, pp. 477-490.

Brans J.P., Vincle, P., 1985, “A Preference Ranking Organization Method”, Manage. Sci. Vol. 31(6), pp. 647-656.

Cheng, S., Chan, C. W., Huang, G. H., 2002, “Using Multiple Criteria Decision Analysis for Supporting Decisions of Solid Waste Management", Journal of Environment Science Health, Vol. 37(6), pp. 975-990.

Eleren, A., Karagül, M., 2008, "1986-2006 Türkiye Ekonomisinin Performans Değerlendirmesi", Celal Bayar Üniversitesi İ̈BF Yönetim ve Ekonomi Dergisi, Vol. 15(1), pp. 1-14.

Ho, W., Xu, X., Dey, P. K., 2010, “Multi-criteria Decision Making Approaches for Supplier Evaluation and Selection: A Literature Review", European Journal of Operational Research, Vol. 202(1), pp. 16-24.

Hwang, C, L., Yoon, K., 1981, Multiple Attribute Decision Making-Methods and Applications, SpringerVerlag, Heidelberg.

Kalkan, S., Turanlı,M., Özden, Ü., Başar, Ö., 2017, Comparison of Ranking Results Obtained by TOPSIS and VIKOR Methods, using the Same Criteria as Times Higher Education World University Ranking", European Journal of Business and Social Sciences, Vol. 6(1), pp. 107-122.

Opricovic, S., 1998, Multicriteria Optimization of Civil EngineeringSystems, Faculty of Civil Engineering, Belgrade.

Opricovic, S., Tzeng, H,G., 2004, "Compromise Solution by MCDM Methods: A Comparative Analysis of VIKOR and TOPSIS", European Journal of Operational Research, Vol. 156, pp. 445-455.

Opricovic, S., Tzeng, G. H., 2007, "Extended VIKOR Method in Comparison with Other Outranking Methods", European Journal of Operational Research, Vol. 178(2), pp. 514-529.

Peters, L., Zelewski, S., 2007, TOPSIS alsTechnikzurEffieienzanalyse, ZeitschriftfürAusbildung und Hochschulkontakt, 1-9.

Saaty, T.L., 1977, "A Scaling Method for Priorities in Hierarchical Structures", Journal of Mathematical Psychology, Vol. 15, pp. 234-281.

Saaty, T.L., 1980, The Analytical Hierarchy Process, New York: Wiley.

Saaty, T.L., 1994, Fundamentals of Decision Making and Priority Theory With The Analytical Hierarchy Process, RWS Publ. Pittsburg, 69-84.

Saaty, T.L., 2001, Decision Making with Dependence and Feedback: The Analytic Network Process, 2nd edition, PRWS Publications, Pittsburgh PA.

Saaty, T.L., Vargas, L.G., 1991, Prediction, Projection and Forecasting Kluwer Academic Publishers, Dordrecht, 25. 
Sakthivel, G., Ilangkumaran, M., Gaikwad, A., 2015, “A Hybrid Multi-Criteria Decision Modeling Approach for the Best Biodiesel Blend Selection based on ANP-TOPSIS Analysis", Ain Shams Engineering Journal, Vol. 6, pp. 239-256.

Senvar, O., Tuzkaya, G., Kahraman, C., 2014, "Multi Criteria Supplier Selection Using Fuzzy PROMETHEE Method. In: Kahraman C., Öztayşi B. (eds) Supply Chain Management Under Fuzziness", Studies in Fuzziness and Soft Computing, Vol 313. Springer, Berlin, Heidelberg.

Triantaphyllou, E., 2000, Multi-Criteria Decision Making Methods: A Comparative Study, Kluwer Academic Publishers, Netherlands, 139-140.

Yu, J., Chen, Y., Wu, J., Khan, S., 2011, “Cellular Automata-Based Spatial Multi-Criteria Land Suitability Simulation for Irrigated Agriculture", Int. J. Geogr. Inform. Sci., Vol. 25 (1), pp. 131-148.

Wang, Y, M., Elhag T, M, S., 2006, "Fuzzy TOPSIS Method Based on Alpha Level Sets with an Application to Bridge Risk Assessment", Expert Systems with Applications, Vol. 31(2), pp. 309319.

Zeleny, M., 1982, Multiple Criteria Decision Making, Mc-Graw-Hill, New York. 